\title{
Effect of Rootstock Cultivar, Pruning Method and Crop Load on Botrytis cinerea Rot of Vitis vinifera $\mathrm{cv}$. Chenin blanc grapes
}

\author{
J.H.S. Ferreira \& P.G. Marais \\ Viticultural and Oenological Research Institute, Private Bag X5026, 7600 Stellenbosch, Republic of South Africa. \\ Submitted for publication: July 1987 \\ Accepted for publication: August 1987 \\ Keywords: Botrytis cinerea, grapevine, rootstock cultivar, pruning method, crop load, Vitis vinifera.
}

\begin{abstract}
The effect of five rootstock cultivars and two pruning methods with two crop loads each on Botrytis cinerea Pers. rot of Vitis vinifera $\mathbf{L}$. cv. Chenin blanc was investigated. The effect of these factors on bunch compactness, berry skin strength, pedicel strength, total soluble solids and nitrogen content of berries was also investigated to determine the correlation between these parameters and botrytis rot. The most rot occurred with Chenin blanc on Ramsey, 110 Richter and 101-14 Mgt when spur pruned, while the least rot occurred with Chenin blanc on 99 Richter when cane pruned.

Rootstock cultivar had a significant effect on bunch compactness, berry skin strength, pedicel strength, cane mass and crop mass while rootstock cultivar and pruning method had a significant effect on total nitrogen and total soluble solids of berries. Except for bunch compactness none of the other parameters appear to have any direct effect on botrytis rot.
\end{abstract}

Control of bunch rot of grapes caused by Botrytis cinerea Pers. is achieved mainly by chemical means. This is an expensive operation; the total cost in South Africa for wine and table grapes is estimated at R2,0 million per season. As a result of the rise in cost of chemical control as well as the fact that strains of $B$. cinerea resistant to some of the fungicides have occurred, it is unlikely that practical control of botrytis bunch rot can be achieved by the use of fungicides alone.

It is known that many cultivation practices which are likely to increase vine vigour, e.g. excessive nitrogen fertilisation, vigorous rootstocks and irrigation, will increase the susceptibility of grapes to $B$. cinerea (Branas, 1960; Champagnol, 1969; Delas, 1972; Dry \& Smart, 1982). Christensen (1981) found that by increasing the number of nodes per vine from 40 to 60 in the case of Chenin blanc, a significant decrease in botrytis bunch rot occurred. Practical experience in European viticultural areas has shown that choice of rootstock and scion cultivar as well as fertiliser application level, are very important factors with regard to control of botrytis bunch rot (Dry \& Smart, 1982).

The present study was carried out to determine the effect of certain cultivation practices, viz. the use of certain rootstock cultivars, pruning method and crop load on the incidence of botrytis rot of Chenin blanc. The effect of these factors on bunch compactness, as well as pedicel strength, berry skin strength, nitrogen and sugar content of berries was also evaluated in order to determine if a relation exists between these parameters and botrytis bunch rot.

\section{MATERIALS AND METHODS}

A fourteen-year-old vineyard at Robertson, consisting of five rootstock cultivars viz. Ramsey, 99 Richter, 110 Richter, 101-14 Mgt and Jacquez with Chenin blanc as scion, was used in this study. Vines were trellised according to the Perold system as described by Zeeman (1981).
A randomized block design in which each rootstock cultivar was replicated four times was used. Each plot consisted of four rows with seven vines per row. Two pruning methods viz. cane pruning and spur pruning were both applied in two adjacent rows. Vines were spaced $1 \mathrm{~m}$ apart in rows with $1,7 \mathrm{~m}$ between rows. One row was allotted 12 buds/ $\mathrm{kg}$ cane mass per vine while a second row was allotted 25 buds $/ \mathrm{kg}$ cane mass per vine, for each pruning method.

A standard disease control program against downy and powdery mildew was followed but no chemical was applied for the control of botrytis bunch rot.

Cane mass was determined during pruning, while crop mass as well as the following was determined at harvest:

\section{Incidence of botrytis rot}

From each treatment 50 bunches per replicate were visually scored for botrytis rot according to the scoring system of Townsend and Heuberger (Kremer \& Unterstenhöfer, 1967). From this the mean percentage botrytis rot was calculated by means of the formula of Unterstenhöfer (1962).

\section{Bunch Compactness}

From each treatment, 20 bunches per replicate were randomly picked and the mass and volume for each bunch determined as follows: A bucket fitted with an overflow pipe was filled to capacity with water. After water ceased dripping from the overflow pipe, bunches, separately placed in polyethylene bags with the air removed by suction, were completely submerged in the water (one bunch per bucket). The water thus displaced was measured in a measuring cylinder. The mass of each bunch was determined and bunch compactness was calculated by dividing bunch mass by bunch volume.

\section{Berry skin strength}

Twenty bunches were randomly picked from each of the four replicates of the different treatments. Two ber-

'Present address: Liquor Control, Private Bag X5026, 7600 Stellenbosch, Republic of South Africa. 
TABLE 1

Significance of different treatments on Botrytis cinerea rot and certain vine parameters.

\begin{tabular}{|c|c|c|c|c|c|c|c|c|}
\hline Treatment & $\begin{array}{l}\text { Botrytis } \\
\text { rot }\end{array}$ & $\begin{array}{c}\text { Bunch com- } \\
\text { pactness }\end{array}$ & $\begin{array}{c}\text { Skin } \\
\text { strength }\end{array}$ & $\begin{array}{l}\text { Pedicel } \\
\text { strength }\end{array}$ & $\begin{array}{l}\text { Cane } \\
\text { mass }\end{array}$ & $\begin{array}{l}\text { Crop } \\
\text { mass }\end{array}$ & $\begin{array}{c}\text { Total } \\
\text { nitrogen }\end{array}$ & $\begin{array}{l}\text { Total solu- } \\
\text { ble solids }\end{array}$ \\
\hline Rootstock cultivar & $\star \star$ & $\star$ & $\star \star$ & $\star \star$ & $\star \star$ & $\star \star$ & $\star \star$ & $\star \star$ \\
\hline Pruning method & $\star \star$ & ns & ns & ns & - & $\star$ & $\star \star$ & ns \\
\hline $\begin{array}{l}\text { Rootstock cultivar } \\
\& \text { pruning method }\end{array}$ & $\star \star$ & ns & ns & ns & - & ns & $\star \star$ & $\star \star$ \\
\hline Bud load & ns & ns & ns & ns & - & $\star \star$ & $\star \star$ & $\star \star$ \\
\hline $\begin{array}{l}\text { Rootstock cultivar } \\
\& \text { bud load }\end{array}$ & ns & ns & ns & $\mathrm{ns}$ & - & ns & $\star \star$ & $\star \star$ \\
\hline $\begin{array}{l}\text { Pruning method \& } \\
\text { bud load }\end{array}$ & ns & ns & ns & ns & - & ns & $\star \star$ & $\star \star$ \\
\hline $\begin{array}{l}\text { Rootstock cultivar } \\
\& \text { pruning method \& } \\
\text { bud load }\end{array}$ & ns & ns & ns & ns & - & ns & $\star \star$ & $\star \star$ \\
\hline
\end{tabular}

$\star \quad$ - Significantly different at $P \leqslant 0,05$

$\star \star-$ Significantly different at $\mathrm{P} \leqslant 0,01$

ries with pedicels intact were randomly cut from each bunch and the skin strength of each berry determined with a Salter pressing machine. The pressure needed to crack the skin was termed the "skin strength".

\section{Pedicel strength}

Pedicel strength was measured with an adapted springbalance measuring the force in gram needed to separate the pedicel from the berry. Sampling of berries for pedicel strength was carried out in the same way and on the same bunches used for determining skin strength.

\section{Nitrogen and total soluble solids}

Berry sampling from each replicate in all treatments was done on a statistical basis as suggested by Du Plessis \& Van Schalkwyk (1974). The berries in each sample were macerated in a mortar, squeezed through a cheesecloth and the juice centrifuged at $3,2 \mathrm{~g}$ for 10 min. The cleared juice was analysed for total soluble solids using an Abbé refractometer. Total nitrogen, was determined using the standard VORI method.

Differentiation of means for all data in the experiment was done by the method of Scott \& Knott (1974).

\section{RESULTS AND DISCUSSION}

\section{Rootstock cultivar and pruning methods}

Rootstock cultivar and pruning method had a highly significant effect on botrytis rot of Chenin blanc while the effect of crop load was non-significant (Table 1). This phenomenon cannot be explained and needs further investigation. Each of the rootstock cultivars except Jacquez, caused a significantly higher percentage rot of Chenin blanc when spur pruned compared with cane pruning (Fig. 1). The low incidence of rot on Jacquez could be attributed to poor foliage development due to the weak growth of this cultivar, as indicated by the cane mass (Table 2), thus causing better aeration and faster drying of bunches after rain or irrigation. The higher incidence of rot on the spur pruned vines compared with cane pruned vines may be the result of a closer spacing of buds on the arms of spur pruned vines which apparently cause a denser foliage with favourable microclimatic conditions for $B$. cinerea infection. The effect of foliage density on the microclimate and hence on disease development is well documented (Rotem \& Palti, 1969). Chenin blanc on Ramsey, 110 Richter and 101-14 Mgt had the highest rot incidence when spur pruned. When cane pruned, Chenin blanc on 110 Richter showed the highest incidence of rot (Fig. 1). Chenin blanc on 99 Richter had the lowest rot incidence of all the rootstock cultivars when cane pruned. These differences in botrytis rot of Chenin blanc on different rootstock cultivars could possibly be attributed to differences in growth between rootstock cultivars as indicated by the cane mass of the different cultivars in Table 2. More vigorous rootstock cultivars cause a denser foliage which could be more favourable for $B$. cinerea infection. The low incidence of rot in the case of a relatively vigorous rootstock like 99 Richter when cane pruned (Fig. 1) is an indication of other factors involved.

TABLE 2

The effect of different rootstock cultivars on bunch compactness, berry skin strength, total cane mass and pedicel strength, of Chenin blanc.

\begin{tabular}{|c|c|c|c|c|}
\hline Rootstock & $\begin{array}{c}\text { Cane } \\
\text { mass per } \\
\text { vine } \\
(\mathrm{kg})\end{array}$ & 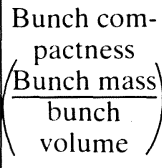 & $\begin{array}{l}\text { Berry } \\
\text { skin } \\
\text { strength } \\
\quad(\mathrm{g})\end{array}$ & $\begin{array}{l}\text { Pedicel } \\
\text { strength } \\
\quad(\mathrm{g})\end{array}$ \\
\hline 110 Richter & $1,95 \mathrm{a}$ & $0.69 \mathrm{a}$ & $833,50 \mathrm{a}$ & $76,68 \mathrm{a}$ \\
\hline Ramsey & $1,90 \mathrm{a}$ & $0,68 \mathrm{a}$ & $689,69 \mathrm{~b}$ & $58,04 \mathrm{~b}$ \\
\hline $101-14 \mathrm{Mgt}$ & $1,19 \mathrm{~b}$ & $0,68 \mathrm{a}$ & $832,19 \mathrm{a}$ & $58,71 \mathrm{~b}$ \\
\hline 99 Richter & $1,04 \mathrm{~b}$ & $0,66 \mathrm{~b}$ & $638,50 \mathrm{~b}$ & $55,23 \mathrm{~b}$ \\
\hline Jacquez & $0,60 \mathrm{c}$ & $0,63 \mathrm{c}$ & $787,63 \mathrm{a}$ & $68,39 \mathrm{a}$ \\
\hline
\end{tabular}

Means in columns followed vertically by different letters differ significantly at $(P \leqslant 0,05)$ 


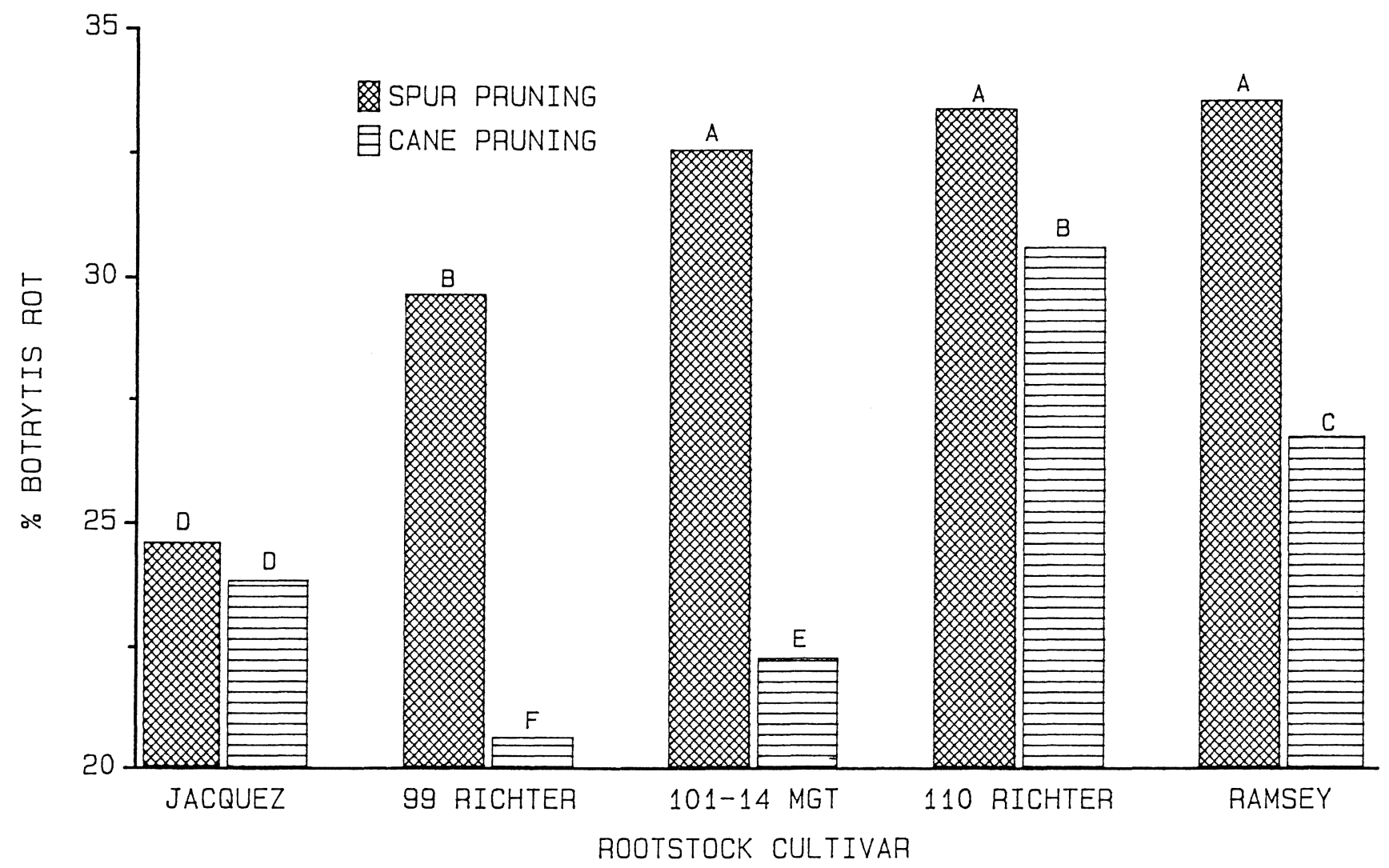

FIG: 1. THE PERCENTAGE BOTRYTIS CINEREA BUNCH ROT OF CHENIN BLANC
GRAFTED TO FIVE ROOTSTOCK CULTIVARS AND PRUNED TO TWO SYSTEMS
BARS WITH DIFFERENT LETTERS DIFFER SIGNIFICANTLY (P\$0.05)

Bunches of Chenin blanc on Jacquez were significantly less compact than those on the other rootstock cultivars (Table 2) which could be due to the poor growth of this cultivar. Chenin blanc on 101-14 Mgt, 110 Richter and Ramsey had significantly more compact bunches than on 99 Richter and Jacquez (Table 2). Chenin blanc on the first three rootstocks also had the highest botrytis incidence when spur pruned (Fig. 1). According to Savage \& Sall (1983) cluster injuries which may result from expansion of berries in compact bunches may be important avenues for $B$. cinerea infection. It therefore seems that rootstock cultivar may have an effect on vigour and bunch compactness, which in turn affects botrytis rot.

Berries of Chenin blanc on 110 Richter, 101-14 Mgt and Jacquez had significantly stronger skins than those of Ramsey and 99 Richter (Table 2). Chenin blanc on 110 Richter and 101-14 Mgt, however, also had a relatively high percentage botrytis rot when spur pruned (Fig. 1). Chenin blanc on Jacquez on the other hand had berries with strong skins and a low percentage botrytis rot (spur and cane pruned) while 99 Richter had berries with weak skins (Table 2) and a low percentage botrytis rot when cane pruned (Fig. 1). Pruning method had no significant effect on skin strength (Table 1). From the data it seems that skin strength of berries as induced by rootstock had no relation to botrytis rot of Chenin blanc.

A significantly stronger force was needed to separate pedicels from berries of Chenin blanc grafted on 110 Richter and Jacquez (Table 2) compared to the rest of the rootstock cultivars. However, in the case of Chenin blanc on Jacquez the botrytis incidence was low (Fig. 1 ), while a higher incidence of botrytis rot occurred in the case of Chenin blanc on 110 Richter (Fig. 1). It therefore appears that pedicel strength as induced by rootstock cultivar does not affect botrytis rot.

\section{Nitrogen and total soluble solids content of berries}

Ramsey and Jacquez induced a significantly higher nitrogen content in the berries at the low bud load (12 buds/kg cane mass) compared with the high bud load (25 buds $/ \mathrm{kg}$ cane mass), for both pruning systems (Table 3). Bud load however, did not have any significant effect on botrytis rot (Table 1).

Significantly higher botrytis rot occurred with Chenin blanc on 99 Richter, 101-14 Mgt, 110 Richter and Ramsey when spur pruned (low and high crop loads) compared with cane pruning (Fig. 1). However, this higher botrytis incidence cannot be attributed to a higher nitrogen content of the berries induced by the pruning system, because only Ramsey and 101-14 Mgt resulted in significantly higher nitrogen content of Chenin blanc berries when spur pruned compared with cane pruning (Table 4).

Dry \& Smart (1982) reported that a high concentration of nitrogen in the berries could favour infection of botrytis rot. In the present study it seems rather unlike- 


\section{TABLE 3}

Mean nitrogen content of Chenin blanc berries on different rootstock cultivars pruned to two systems with different bud loads.

\begin{tabular}{l|c|c|c|c|c}
\hline \multirow{1}{*}{$\begin{array}{l}\text { Pruning } \\
\text { system }\end{array}$} & \multicolumn{5}{c}{ Nitrogen content $(\mathrm{mg} / \mathrm{l})$} \\
\cline { 2 - 6 } & $\begin{array}{c}\text { Jac- } \\
\text { quez }\end{array}$ & $\begin{array}{c}99 \\
\text { Richter }\end{array}$ & $\begin{array}{c}101-14 \\
\text { Mgt }\end{array}$ & $\begin{array}{c}110 \\
\text { Richter }\end{array}$ & $\begin{array}{c}\text { Ram- } \\
\text { sey }\end{array}$ \\
\hline $\begin{array}{l}\text { Spur 12 buds/kg } \\
\text { cane mass }\end{array}$ & $450 \mathrm{a}$ & $450 \mathrm{a}$ & $400 \mathrm{a}$ & $375 \mathrm{a}$ & $675 \mathrm{a}$ \\
$\begin{array}{l}\text { Spur 25 buds/kg } \\
\text { cane mass }\end{array}$ & $400 \mathrm{~b}$ & $450 \mathrm{a}$ & $525 \mathrm{~b}$ & $375 \mathrm{a}$ & $625 \mathrm{~b}$ \\
$\begin{array}{l}\text { Cane } 12 \mathrm{buds} / \mathrm{kg} \\
\text { cane mass }\end{array}$ & $450 \mathrm{a}$ & $450 \mathrm{a}$ & $500 \mathrm{c}$ & $375 \mathrm{a}$ & $500 \mathrm{c}$ \\
$\begin{array}{l}\text { Cane 25 buds/kg } \\
\text { cane mass }\end{array}$ & $425 \mathrm{c}$ & $450 \mathrm{a}$ & $400 \mathrm{a}$ & $375 \mathrm{a}$ & $450 \mathrm{~d}$ \\
\hline
\end{tabular}

Means in columns followed vertically by different letters differ significantly $(\mathrm{P} \leqslant 0,05)$

ly that the nitrogen content played any significant role in the incidence of botrytis rot of Chenin blanc.

Although total soluble solids content of berries is known to influence botrytis rot it seems that the differences in total soluble solids content that did occur with the different pruning systems (Table 5) did not have any significant influence on botrytis rot. For instance, of the cultivars which had a high percentage botrytis rot when spur pruned (Fig. 1), only 101-14 Mgt had a significantly higher total soluble solid content when spur pruned (low and high crop loads) compared with cane pruning at corresponding crop levels.

TABLE 4

Nitrogen content of berries from Chenin blanc on different rootstocks and pruned to two systems.

\begin{tabular}{l|c|c|c|c|c}
\hline \multirow{4}{*}{$\begin{array}{c}\text { Pruning } \\
\text { system }\end{array}$} & \multicolumn{4}{|c}{ Mean nitrogen content $(\mathrm{mg} / \mathrm{l})$} \\
\cline { 2 - 6 } & $\begin{array}{c}\text { Jac- } \\
\text { quez }\end{array}$ & $\begin{array}{c}99 \\
\text { Richter }\end{array}$ & $\begin{array}{c}101-14 \\
\text { Mgt }\end{array}$ & $\begin{array}{c}110 \\
\text { Richter }\end{array}$ & $\begin{array}{c}\text { Ram- } \\
\text { sey }\end{array}$ \\
\hline Spur & $425,0 \mathrm{a}$ & $450 \mathrm{a}$ & $462,5 \mathrm{a}$ & $375 \mathrm{a}$ & $650 \mathrm{a}$ \\
Cane & $437,5 \mathrm{~b}$ & $450 \mathrm{a}$ & $450,0 \mathrm{~b}$ & $375 \mathrm{a}$ & $475 \mathrm{~b}$ \\
\hline
\end{tabular}

Means in columns followed vertically by different letters differ significantly $(\mathrm{P} \leqslant 0,05)$

TABLE 5

Mean total soluble solids of Chenin blanc berries on different rootstocks pruned to two systems.

\begin{tabular}{l|c|c|c|c|c}
\hline \multirow{3}{*}{$\begin{array}{c}\text { Pruning } \\
\text { system }\end{array}$} & \multicolumn{4}{|c}{ Total soluble solids mg/l } \\
\cline { 2 - 6 } & $\begin{array}{c}\text { Jac- } \\
\text { quez }\end{array}$ & $\begin{array}{c}99 \\
\text { Richter }\end{array}$ & $\begin{array}{c}101-14 \\
\text { Mgt }\end{array}$ & $\begin{array}{c}110 \\
\text { Richter }\end{array}$ & $\begin{array}{c}\text { Ram- } \\
\text { sey }\end{array}$ \\
\hline Spur & $19,4 \mathrm{a}$ & $19,2 \mathrm{a}$ & $19,4 \mathrm{a}$ & $18,7 \mathrm{a}$ & $18,9 \mathrm{a}$ \\
Cane & $19,8 \mathrm{~b}$ & $19,3 \mathrm{a}$ & $18,7 \mathrm{~b}$ & $19,0 \mathrm{~b}$ & $19,1 \mathrm{~b}$ \\
\hline
\end{tabular}

Means in columns followed vertically by different letters differ significantly $(P \leqslant 0,05)$

\section{CONCLUSIONS}

Rootstock cultivar/pruning method interaction had a significant effect on botrytis rot of Chenin blanc as well as on total nitrogen and total soluble solids. Rootstock cultivar affected bunch compactness, berry skin strength and cane mass. However, except for bunch compactness, none of these other parameters had an effect on botrytis incidence.

The choice of 99 Richter as rootstock cultivar cane pruned could aid in the control of botrytis rot of Chenin blanc.

\section{LITERATURE CITED}

BRANAS, J., 1960. La Pourriture des raisins. Prog. agric. vitic. 17, 125-130.

CHAMPAGNOL, F., 1969. Relations entre la croissance in vitro de Botrytis cinerea la composition des mouts de raisin. C. r. Acad. Agric. Fr. 55, 1082-1097.

CHRISTENSEN, L.P., 1981. Lighter pruning lessens bunch rot of Chenin blanc grapes. Calif. Agric. March-April, 10-11.

DELAS, J., 1972. Effects de la fertilisation de la Vigne sur le developement de Botrytis cinerea. Rev. Zool. Agric Parth rég. 11-17.

DRY, P. \& SMART, R., 1982. Control of Botrytis bunch rot requires integrated approach. The Australian Grapegrower and Winemaker 226, 30

DU PLESSIS, C.S. \& VAN SCHALKWYK, D.J., 1974. Reliable berry sampling and sugar determination in grapes. Oenological and Viticultural serie G1. VORI, 7600 Stellenbosch, Republic of South Africa.

KREMER, F. \& UNTERSTENHÖFER, G., 1967. Computation of results of crop protection experiments by the method of Townsend and Heuberger. Pflanzenschutz-nachrichten 20, 625-628.

ROTEM, J. \& PALTI, J., 1969. Irrigation and plant diseases. Ann. Rev. Phytopath. 7, 267-288.

SAVAGE, S.D. \& SALL, M.A., 1983. Botrytis bunch rot of grapes: The influence of selected cultural practices on infection under California conditions. Plant Disease 67, 771-774.

SCOTT, A.J. \& KNOTT, M., 1974. A cluster analysis method for grouping means in the analysis of variance. Biometrics 30, 507510 .

UNTERSTENHÖFER, G., 1962. The basic principles of crop protection field trials. Pflanzenschutz-nachrichten 16, 81-162.

ZEEMAN, A.S., 1981. Stokontwikkeling, wintersnoei en somerbehandeling. pp. 185-198. In: Wingerdbou in Suid-Afrika. J. Burger \& J. Deist (eds.) VORI, Private Bag X5026, 7600 Stellenbosch, Republic of South Africa. 